\title{
PENGARUH PEMANFAATAN LIMBAH CAIR PABRIK KELAPA SAWIT TERHADAP SIFAT KIMIA DAN FISIKA TANAH PADA LAHAN PERKEBUNAN KELAPA SAWIT MILIK PT.PMP KABUPATEN MAYBRAT
}

\author{
The Effect Of The Utilization Of Palm Oil Mill Effluent On The Chemical And Physical \\ Properties Of Soil In Palm Oil Plantation Owned By PT. PMP Maybrat District
}

\author{
Aprilia Regita Sari ${ }^{1}$, Markus Heryanto Langsa ${ }^{1 *}$, Alfhons Daniel Sirampun ${ }^{1}$ \\ Jurusan Kimia, FMIPA, Universitas Papua, Manokwari, 98314, Indonesia \\ *email korespondensi: m.langsa@unipa.ac.id
}

\begin{abstract}
ABSTRAK
Limbah cair pabrik kelapa sawit (LCPKS) adalah limbah yang paling banyak dihasilkan dari pabrik kelapa sawit. LCPKS hasil buangan dari pabrik kelapa sawit dapat mencemari lingkungan di sekitarnya. Tujuan utama penelitian ini adalah untuk mengetahui pemanfaatan LCPKS terhadap kesuburan tanah dan peningkatan pertumbuhan tanaman kelapa sawit serta meminimalkan dampak negatif terhadap lingkungan. Hasil penelitian yang didapat merupakan gabungan antara data primer (hasil analisis yang dilakukan di perkebunan kelapa sawit milik PT.PMP, Kabupaten Maybrat sebelum aplikasi LCPKS) dan data sekunder (hasil analisis yang dilakukan di perkebunan kelapa sawit Angsana Estate, Kalimantan Selatan setelah aplikasi LCPKS). Dari hasil yang diperoleh menunjukkan bahwa umumnya setelah aplikasi LCPKS ke lahan akan meningkatkan nilai bobot isi serta menurunkan nilai porositas tanah dan permeabilitas tanah. Terjadi penurunan persen porositas tanah pada lahan aplikasi (LA, 28,75\% dan Parit, 23,47\%) dibandingkan dengan tanpa aplikasi ( LK, 36,83\%) pada ke dalaman tanah hingga $30 \mathrm{~cm}$. Pada tanah dengan kedalaman yang lebih dalam $(30-60 \mathrm{~cm})$ persen penurunan tanah hampir sama dengan pada kedalaman $30 \mathrm{~cm}$. Sebaliknya penambahan LCPKS di lahan aplikasi (LA) berdampak pada penambahan bobot isi $\left(1,81 \mathrm{~g} / \mathrm{cm}^{3}\right)$ dan permeabilitas tanah $(4,16 \mathrm{~cm} / \mathrm{jam})$ dibandingkan tanpa LCPKS (LK) $\left(1,48 \mathrm{~g} / \mathrm{cm}^{3}\right.$ dan 4,08 $\mathrm{cm} / \mathrm{jam}$ ) untuk sampel tanah dikedalaman $30 \mathrm{~cm}$. Aplikasi LCPKS menambah ketersediaan kandungan bahan organik (C-organik dan nitrogen) pada tanah bagian permukaan. Nilai P-tersedia paling tinggi terlihat pada kedalaman $0-20 \mathrm{~cm}$ dan $20-40 \mathrm{~cm}$ di dalam parit. Serta, LCPKS pada lahan kelapa sawit cenderung meningkatkan kadar unsur hara pada daun kelapa sawit dibandingkan dengan lahan kontrol (tanpa LCPKS).
\end{abstract}

Kata kunci : LCPKS, kelapa sawit, sifat fisika tanah, sifat kimia tanah, unsur hara.

\begin{abstract}
Palm oil mill effluent (POME) is the most abundant waste produced from palm oil mills. POME waste products from palm oil mills can pollute the surrounding environment. The main objective of this study was to determine the use of POME on soil fertility and increase the growth of oil palm plants and minimize negative impacts on the environment. The results of the research obtained are a combination of primary data (results of analysis carried out in oil palm plantations owned by PT PMP, Maybrat Regency before the POME application) and secondary data (results of analysis carried out at Angsana Estate oil palm plantations, South Kalimantan after POME application). The results obtained indicate that generally after the application of POME to the land will increase the value of the bulk density and decrease the value of soil porosity and soil permeability. There was a decrease in the percentage of soil porosity in the application area (LA, 28.75\% and Flatbed, $23.47 \%$ ) compared to without application (LK, 36.83\%) in the soil depth up to $30 \mathrm{~cm}$. On soils with a deeper depth $(30-60 \mathrm{~cm})$ the percent of land subsidence is almost the same as at a depth of 30 $\mathrm{cm}$. Conversely, the addition of POME in the land application (LA) had an impact on the increase in bulk density $(1.81 \mathrm{~g} / \mathrm{cm} 3)$ and soil permeability $(4.16 \mathrm{~cm} /$ hour) compared without POME (LK) $(1.48 \mathrm{~g} / \mathrm{cm} 3$ and $4.08 \mathrm{~cm} /$ hour) for soil samples to a depth of $30 \mathrm{~cm}$. The POME application increases the availability of organic matter (C-organic and nitrogen) in the surface soils. The highest P-available values are seen at a depth of $0-20 \mathrm{~cm}$ and $20-40 \mathrm{~cm}$ in the flatbed. Also, POME on oil palm land tends to increase nutrient content in oil palm leaves compared to control land (without POME).
\end{abstract}

Keyword: POME, oil palm, soil physical properties, soil chemical properties, nutrients 


\section{PENDAHULUAN}

Kelapa Sawit (Elaeis guineensis Jacq.) merupakan salah satu jenis tanaman perkebunan yang memiliki nilai ekonomis yang sangat tinggi. Kelapa sawit memegang peranan penting dalam sektor perekonomian Indonesia yaitu sebagai penyumbang devisa non-migas yang cukup besar. Kelapa Sawit menghasilkan produk olahan yang memiliki banyak manfaat. Luas perkebunan Kelapa sawit di Indonesia pada tahun 2019 diperkirakan mencapai 14.677.560 hektar (Direktorat Jenderal Perkebunan, 2019)

Areal kelapa sawit yang tinggi berbanding lurus dengan jumlah produksi produk olahan kelapa sawit yang dihasilkan. Semakin tinggi produk olahan kelapa sawit, semakin besar juga dampak berupa jumlah limbah yang dihasilkan terhadap lingkungan. Menurut Direktorat Jenderal Perkebunan (2014), jumlah pabrik kelapa sawit adalah sebanyak 608 pabrik. Pabrik kelapa sawit menghasilkan tiga jenis limbah yaitu limbah padat, cair, dan gas (Wahyudi et al., 2011). Limbah cair pabrik kelapa sawit atau disingkat LCPKS adalah limbah yang paling banyak dihasilkan dari pabrik kelapa sawit.

LCPKS hasil buangan dari pabrik kelapa sawit dapat mencemari lingkungan di sekitarnya (Roslan et al., 2009). LCPKS yang dibuang langsung ke sungai dapat menyebabkan kerusakan ekosistem perairan di sungai (Rahayu et al., 2014). Sedangkan LCPKS yang dibuang ke tanah akan menyebabkan menurunnya jumlah mikroorganisme tanah yang nantinya akan berdampak pada ekosistem tanah (Orji et al., 2006).

Limbah cair pabrik kelapa sawit (LCPKS) bersifat asam dengan $\mathrm{pH}$ sekitar 3,3 - 4,6, berwarna kecoklatan dengan kandungan BOD (Biochemical Oxygen Demand) sekitar 8.200 $35.000 \mathrm{mg} / \mathrm{L}$ dan COD (Chemical Oxygen Demand) sekitar 15.103 - $65.100 \mathrm{mg} / \mathrm{L}$ (Rahayu, et al., 2014). Adanya kandungan COD dan BOD yang tinggi ini dikhawatirkan akan menyebabkan menurunnya kualitas air tanah di sekitar tempat pembuangan limbah. LCPKS juga menimbulkan bau tidak sedap yang dapat meningkatkan populasi lalat sehingga mengganggu masyarakat sekitar (Loekito, 2002).
Selain dari dampak negatif yang dihasilkan, LCPKS mempunyai kandungan bahan organik yang tinggi sehingga dapat dimanfaatkan untuk dijadikan pupuk organik (Susilawati \& Supijatno, 2015). Pupuk organik merupakan pupuk yang berasal dari tumbuhan mati, kotoran hewan dan/atau bagian hewan dan/atau limbah organik lainnya yang telah melalui proses rekayasa, berbentuk padat atau cair, dapat diperkaya dengan bahan mineral dan/atau mikroba yang bermanfaat untuk meningkatkan kandungan hara dan bahan organik tanah serta memperbaiki sifat fisik, kimia, dan biologi tanah (Peraturan Menteri Pertanian No.70 Tahun 2011).

LCPKS memiliki sejumlah kandungan unsur hara yang diperlukan tanaman yaitu N, P, $\mathrm{K}, \mathrm{Ca}$, dan $\mathrm{Mg}$ yang berpotensi sebagai sumber hara bagi tanaman (Budianta, 2005). Menurut Peraturan Menteri Negara Lingkungan Hidup No. 28 Tahun 2003 tentang Pedoman Teknis Pengkajian Pemanfaatan Air Limbah dari Industri Minyak Sawit pada Tanah di Perkebunan Kelapa Sawit, pihak pabrik kelapa sawit diperkenankan memanfaatkan LCPKS sebagai pupuk cair setelah melalui kajian yang mendalam dan mendapat persetujuan dari pemerintah daerah setempat. Kajian yang dilakukan untuk memastikan kandungan senyawa organik yang terkandung dalam LCPKS memenuhi nilai baku mutu yang dipersyaratkan sehingga layak dimanfaatkan sebagai pupuk cair dan tidak berdampak negatif terhadap lingkungan. Pemanfaatan LCPKS sebagai pupuk organik cair dapat menjadi salah satu cara terbaik untuk mengurangi jumlah limbah yang dihasilkan dari pabrik kelapa sawit selain itu juga dapat meningkatkan pertumbuhan tanaman dan produksi tandan buah segar kelapa sawit.

Tujuan utama dari kajian pemanfaatan LCPKS pada tanah di lahan perkebunan kelapa sawit adalah untuk mengetahui pemanfaatan LCPKS terhadap kesuburan tanah dan peningkatan pertumbuhan tanaman kelapa sawit serta meminimalkan dampak negatif terhadap lingkungan. Untuk mencapai tujuan tersebut, penelitian ini difokuskan pada:

a. Karakterisasi LCPKS yang ada di kolam akhir IPAL 
b. Karakterisasi sifat fisik dan kimia/mineral tanah sebelum dan setelah LCPKS diaplikasikan.

c. Karakterisasi unsur hara pada daun tanaman kelapa sawit sebelum dan setelah LCPKS diaplikasikan.

d. Menentukan apakah terdapat peningkatan unsur hara pada tanah dan daun tanaman kelapa sawit setelah penggunaan LCPKS.

\section{METODE PENELITIAN}

\section{Pengambilan Sampel}

Sampel yang diambil berupa sampel limbah cair pabrik kelapa sawit (LCPKS), sampel tanah, dan sampel daun kelapa sawit. Khusus untuk sampel tanah, diambil tanah pada lahan aplikasi/pemanfaatan limbah cair, lahan kontrol, dan di dalam parit. Sampel LCPKS diambil dari kolam IPAL (kolam akhir) LCPKS yang dihasilkan dari pabrik kelapa sawit dari PT. PMP yang terletak di Kab. Meybrat dan Kab. Sorong Selatan, Papua Barat. Prosedur pengambilan sampel mengacu pada SNI 6989.59:2008 tentang Metoda Pengambilan Contoh Air Limbah. Alat yang digunakan untuk pengambilan sampel terbuat dari bahan yang tidak mempengaruhi sifat sampel, mudah dicuci dari bekas sampel sebelumnya, sampel mudah dipindahkan ke dalam botol penampung tanpa ada sisa bahan tersuspensi di dalamnya, mudah dan aman untuk dibawa.

Sampel tanah diambil dari tiga lokasi, yaitu lahan aplikasi, lahan kontrol, dan parit di sekitar perkebunan kelapa sawit yang terdapat di PT. PMP. Metode pemberian LCPKS pada lahan aplikasi yang dipakai oleh PT. PMP adalah parit bersekat (flatbed) dengan ukuran parit $20 \times 1 \times 0,8 \mathrm{~m}$ dimana pada 1 ha lahan aplikasi dibuat 26 parit. Gambaran penentuan lokasi pengambilan sampel tanah pada aplikasi lahan selengkapnya disajikan pada Lampiran 1 . Sampel tanah diambil dalam keadaan lembab, tidak terlalu basah atau kering dengan menggunakan bor tanah pada kedalaman 0-120 $\mathrm{cm}$ dimana sampel tanah diambil pada kedalaman interval $20 \mathrm{~cm}$.. Kemudian sampel diaduk merata dalam ember untuk menghomogenkannya. Setelah dimasukkan kedalam kantong plastik yang sudah diberi label (Balai Penelitian Tanah, 2005).

Sampel daun kelapa sawit diambil menggunakan metode LSU (Leaf Sampling
Unit), daun yang diambil adalah daun pada pelepah ke-17. Pelepah yang akan diambil daunnya dipotong. Helai daun yang telah diambil, dipotong menjadi 3 bagian yaitu pangkal, tengah, dan ujung. Daun dan lidinya dipisahkan. Sampel kemudian dikeringkan dalam oven pada suhu $70-80^{\circ} \mathrm{C}$ selama $12-24$ jam. Daun yang sudah kering dimasukkan ke dalam kantong dan diberi label. Pengambilan sampel daun dilakukan antara pukul 08.0011.00 dan tidak boleh dilakukan pada hari hujan. Hal ini karena jika ada uap air yang menempel di daun akan mengganggu proses persiapan sampel (Balai Penelitian Tanah, 2005).

\section{Uji Kualitas Air Limbah}

Beberapa parameter untuk menguji kualitas air limbah industri tercantum dalam KEPMENLH Nomor 28 Tahun 2003 Tentang Pedoman Teknis Pengkajian Pemanfaatan Air Limbah Dari Industri Minyak Sawit Pada Tanah di Perkebunan Kelapa Sawit. Parameter tersebut diantaranya $\mathrm{pH}, \mathrm{BOD}, \mathrm{COD}$, Minyak dan Lemak serta beberapa kation seperti $\mathrm{Pb}$, $\mathrm{Cu}, \mathrm{Cd}$, dan $\mathrm{Zn}$.

Nilai $\mathrm{pH}$ sampel air limbah dan air permukaan diukur menggunakan alat $\mathrm{pH}$ meter yang mengacu pada metoda SNI 06-6989.112004. Pertama-tama elektroda dikeringkan dengan kertas tisu selanjutnya dibilas dengan aquades. Kemudian bilas elektroda menggunakan sampel yang akan diuji. Selanjutnya celupkan elektoda kedalam sampel uji sampai $\mathrm{pH}$ meter menujukkan pembacaan yang tepat.

Kadar $\mathrm{BOD}_{5}$ diukur menggunakan SNI 6989-72-2009. Sejumlah sampel uji ditambahkan kedalam larutan pengencer jenuh oksigen yang telah ditambahkan larutan nutrisi dan bibit mikroba, kemudian diinkubasi dalam ruang gelap pada suhu $20^{\circ} \mathrm{C} \pm 1^{\circ} \mathrm{C}$ selama 5 hari. Nilai BOD dihitung berdasarkan selisih konsentrasi oksigen terlarut 0 hari dan 5 hari. Bahan kontrol standar dalam uji BOD ini adalah larutan glukosa-asam glutamat.

Kadar COD diukur dengan refluks terbuka secara titrimetri yang mengacu pada metoda SNI 06-6989.15-2004. Sampel uji dioksidasi dengan campuran mendidih asam sulfat dan kalium dikromat yang diketahui normalitasnya dalam suatu refluk selama 2 jam. Kelebihan 
kalium dikromat yang tidak tereduksi, dititrasi dengan larutan ferro ammonium sulfat (FAS) dan dihitung untuk mengetahui kadar COD nya.

Kadar Minyak dan lemak diukur secara gravimetri yang mengacu pada metode SNI 6989.10.2011. Minyak dan lemak dalam sampel uji air diekstraksi dengan pelarut organik dalam corong pisah dan untuk menghilangkan air yang masih tersisa digunakan $\mathrm{Na}_{2} \mathrm{SO}_{4}$ anhidrat. Ekstrak minyak dan lemak dipisahkan dari pelarut organik secara destilasi. Residu yang tertinggal pada labu destilasi ditimbang sebagai minyak dan lemak.

Sedangkan untuk parameter kation diukur dengan metode yang mengacu pada APHA Ed.23rd 3120.B,3030.E-2017 yaitu menggunakan analisis ICP (Inductively Coupled Plasma) dengan prinsip pengatomisasian elemen sehingga memancarkan cahaya dengan panjang gekombang tertentu yang kemudian dapat diukur.

\section{Uji Kualitas Tanah}

Untuk uji kualitas tanah dilakukan dua kali uji yaitu uji kualitas pada tanah sebelum diberi limbah LCPKS dan uji kualitas pada tanah setelah diberi limbah LCPKS. Uji tanah juga dilakukan pada lahan kontrol yang ditanami kelapa sawit dengan jenis yang sama pada lahan aplikasi LCPKS tetapi tanpa perlakuan/pemberian LCPKS.

Nilai $\mathrm{pH}$ tanah diukur menggunakan metode elektrometri dengan alat $\mathrm{pH}$ meter yang mengacu pada metoda SNI 06-6989.11-2004. Pertama-tama elektroda dikeringkan dengan kertas tisu selanjutnya dibilas dengan aquades. Kemudian bilas elektroda menggunakan sampel yang akan diuji. Selanjutnya celupkan elektoda kedalam sampel uji sampai $\mathrm{pH}$ meter menujukkan pembacaan yang tepat.

Nilai C-organik diukur menggunakan metode Walkley and Black yaitu dengan menambahkan larutan $\mathrm{K}_{2} \mathrm{Cr}_{2} \mathrm{O}_{7} \quad 1 \mathrm{~N}$ dimana karbon sebagai senyawa organik akan mereduksi $\mathrm{Cr}^{6+}$ yang berwarna jingga menjadi $\mathrm{Cr}^{3+}$ yang berwarna hijau dalam suasana asam. Intensitas warna hijau yang terbentuk setara dengan kadar karbon dan dapat diukur dengan spektofotometer pada panjang gelombang 561 nm. (Balai Penelitian Tanah, 2005)

Uji analisis untuk N-total menggunakan metode Kjeldahl yaitu metode analisis dengan mengoksidasi nitogen organik dalam lingkungan asan sulfat pekat dengan katalis campuran selen membentuk $\left(\mathrm{NH}_{4}\right)_{2} \mathrm{SO}_{4}$. Kadar Amonium dapat ditetapkan dengan cara destilasi. Ekstrak dibasakan dengan penambahan larutan $\mathrm{NaOH}$. Selanjutnya, $\mathrm{NH}_{3}$ yang dibebaskan diikat dengan asam borat dan dititrasi dengan larutan baku $\mathrm{H}_{2} \mathrm{SO}_{4}$ dengan menggunakan indikator Conway. (Balai Penelitian Tanah, 2005)

Nilai P-tersedia ditetapkan dengan menggunakan pengekstrak $\mathrm{HCl} 25 \%$. Pengekstrak ini akan melarutkan bentuk-bentuk senyawa fosfat. Ion fosfat dalam ekstrak akan bereaksi dengan ammonium molibdat dalam suasana asam membentuk asam fosfomolibdat. Selanjutnya akan bereaksi dengan asam askorbat menghasilkan larutan biru molibdat. Intensitas warna larutan yang terbentuk setara dengan kadar P-Tersedia dan dapat diukur dengan spektofotometer pada panjang gelombang $693 \mathrm{~nm}$.

Beberapa kation seperti $\mathrm{Ca}, \mathrm{Mg}, \mathrm{K}$, dan $\mathrm{Na}$ juga dilakukan analisis. . Uji analisis Kalsium (Ca) dan Magnesium (Mg) dilakukan dengan metode AAS. Uji analisis Kalium $(\mathrm{K})$ dan Natrium (Na) diukur dengan alat fotometer nyala dengan deret standar sebagai pembanding.

Selanjutnya beberapa logam berat seperti $\mathrm{Pb}, \mathrm{Cu}, \mathrm{Cd}$, dan $\mathrm{Zn}$ juga dilakukan analisis. Analisis unsur logam berat pada tanah dapat diekstrak dengan cara pengabuan basah mengunakan asam campur pekat $\mathrm{HNO}_{3}$ dan $\mathrm{HClO}_{4}$. Kadar logam berat dalam ekstrak dapat diukur menggunakan AAS.

Kemudian dilakukan uji untuk menentukan tekstur dari sampel tanah tersebut. Analisis berdasarkan metode gravimetri atau pengukuran dengan bantuan Hidrometer. Penetapan tekstur berdasarkan pengukuran berat jenis suspensi tanah. Kadar butiran tanah dapat diketahui dari selisisih berat jenis suspensi dengan berat jenis cairan media. Hidrometer yang digunakan dibuat khusus untuk pengukuran berat jenis suspensi tanah. Hidrometer tipe $152 \mathrm{H}$ memiliki pembagian 
skala yang dibuat langsung dalam satuan kadar partikel $\mathrm{g} / 1$.

Kadar Minyak dan lemak diukur secara gravimetri menggunakan sokletasi yang mengacu pada metode SNI 6989.10.2011. Minyak dan lemak dalam sampel uji air diekstraksi dengan pelarut organik dalam corong pisah dan untuk menghilangkan air yang masih tersisa digunakan $\mathrm{Na}_{2} \mathrm{SO}_{4}$ anhidrat. Ekstrak minyak dan lemak dipisahkan dari pelarut organik secara destilasi. Residu yang tertinggal pada labu destilasi ditimbang sebagai minyak dan lemak.

\section{Uji Kualitas Tanaman (Unsur Hara pada Daun Kelapa Sawit)}

Untuk uji kualitas tanaman yaitu unsur hara pada daun kelapa sawit dilakukan uji analisis untuk beberapa parameter yaitu diantaranya unsur hara makro yang terdiri dari N-Total, Fosfor (P), Kalium (K), Magnesium $(\mathrm{Mg})$, Kalsium (Ca), Sulfur (S), dan unsur hara mikro yang terdiri dari Boron (B), Tembaga $(\mathrm{Cu})$, Seng ( $\mathrm{Zn})$, Besi $(\mathrm{Fe})$, Mangan $(\mathrm{Mn})$ dan Klor $(\mathrm{Cl})$.

Uji analisis untuk N-total menggunakan metode Kjeldahl yaitu metode analisis dengan mengoksidasi nitogen organik dalam lingkungan asan sulfat pekat dengan katalis campuran selen membentuk $\left(\mathrm{NH}_{4}\right)_{2} \mathrm{SO}_{4}$. Kadar Amonium dapat ditetapkan dengan cara destilasi. Ekstrak dibasakan dengan penambahan larutan $\mathrm{NaOH}$. Selanjutnya, $\mathrm{NH}_{3}$ yang dibebaskan diikat dengan asam borat dan dititrasi dengan larutan baku $\mathrm{H}_{2} \mathrm{SO}_{4}$ dengan menggunakan indikator Conway.

Unsur hara makro dan mikro total dalam tanah dapat diekstrak dengan cara pengabuan basah menggunakan campuran asam pekat $\mathrm{HNO}_{3}$ dan $\mathrm{HClO}_{4}$. Kadar unsur makro dan mikro dalam ekstrak diukur menggunakan spektofotometer serapan atom (SSA), fotometer nyala, dan spektofotometer.

Untuk uji unsur hara makro, uji analisis fosfor (P) dilakukan dengan metode spektofotometri. Kadar P dalam larutan ekstrak diukur dengan alat spektofotometer pada panjang gelombang $693 \mathrm{~nm}$. Uji analisis Kalsium (Ca) dan Magnesium (Mg) dilakukan dengan metode AAS. Uji analisis Kalium $(\mathrm{K})$ dan Natrium $(\mathrm{Na})$ diukur dengan alat fotometer nyala dengan deret standar sebagai pembanding.

Untuk uji unsur hara mikro, Uji analisis Boron (B) dilakukan dengan metode spektrofometri. Kadar Boron dalam larutan ekstrak diukur dengan alat spektrofotometer pada panjang gelombang $430 \mathrm{~nm}$. Uji analisis Tembaga ( $\mathrm{Cu})$, Seng ( $\mathrm{Zn})$, Besi $(\mathrm{Fe})$, Mangan $(\mathrm{Mn})$ dan Klor $(\mathrm{Cl})$ diukur langsung dari ekstrak contoh menggunakan AAS, dengan deret standar masing-masing sebagai pembanding.

\section{HASIL DAN PEMBAHASAN}

Hasil penelitian yang dipaparkan dalam bab ini merupakan gabungan antara data primer (hasil analisis yang dilakukan di perkebunan kelapa sawit milik PT.PMP, Kabupaten Maybrat sebelum aplikasi LCPKS) dan data sekunder (hasil analisis yang dilakukan di perkebunan kelapa sawit Angsana Estate, Kalimantan Selatan setelah aplikasi LCPKS). Penggunaan data sekunder ini hanya sebagai pembanding untuk mengetahui dampak aplikasi LCPKS di lahan kelapa sawit dikarenakan hingga laporan ini dibuat fasilitas utama dan penunjang aplikasi LCPKS di lapangan belum selesai. Hal ini berdampak pada penundaan rencana aplikasi LCPKS ke lahan dari jadwal semula.

\section{Hasil Analisis LCPKS}

Pabrik kelapa sawit umumnya memiliki instalasi pengolahan air limbah (IPAL) berupa kolam pengolahan untuk mengolah LCPKS agar memenuhi nilai baku mutu sesuai dengan standar yang telah ditetapkan pemerintah. Nilai baku mutu untuk LCPKS mengacu pada KEPMENLH Nomor 28 Tahun 2003 Tentang Pedoman Teknis Pengkajian Pemanfaatan Air Limbah Dari Industri Minyak Sawit Pada Tanah di Perkebunan Kelapa Sawit. Hasil analisis LCPKS PT. PMP yang diambil pada kolam akhir IPAL dapat dilihat pada Tabel 1.

Tabel 1. Hasil analisis LCPKS kolam akhir IPAL PT. PMP

\begin{tabular}{clcc}
\hline No. & Parameter & Satuan & Hasil \\
\hline 1. & $\mathrm{BOD}_{5}$ & $\mathrm{mg} / \mathrm{L}$ & 5.270 \\
\hline
\end{tabular}




\begin{tabular}{clcc}
\hline 2. & COD & $\mathrm{mg} / \mathrm{L}$ & 13.869 \\
\hline 3. & Ph & - & 5 \\
\hline 4. & $\begin{array}{l}\text { Minyak dan } \\
\text { Lemak }\end{array}$ & $\mathrm{mg} / \mathrm{L}$ & 90 \\
\hline 5. & $\begin{array}{l}\text { Timbal } \\
(\mathrm{Pb})\end{array}$ & $\mathrm{mg} / \mathrm{L}$ & $<0,009$ \\
\hline 6. & $\begin{array}{l}\text { Tembaga } \\
(\mathrm{Cu})\end{array}$ & $\mathrm{mg} / \mathrm{L}$ & $<0,005$ \\
\hline 7. & $\begin{array}{l}\text { Kadmium } \\
(\mathrm{Cd})\end{array}$ & $\mathrm{mg} / \mathrm{L}$ & $<0,0006$ \\
\hline 8. & Seng $(\mathrm{Zn})$ & $\mathrm{mg} / \mathrm{L}$ & 0,6 \\
\hline
\end{tabular}

Limbah yang dianalisis merupakan limbah yang berasal dari kolam akhir IPAL yang artinya limbah sudah melewati proses pengolahan terlebih dahulu. Proses pengolahan LCPKS di kolam IPAL meliputi kolam pendinginan, kolam pengasaman dan kolam anaerob. Dari hasil yang diperoleh dapat dilihat bahwa limbah sudah mengalami penurunan kadar pencemar yang cukup signifikan jika dibandingkan dengan rentang rata-rata kadar pencemar limbah tanpa diolah menurut Rahayu, et.al, 2014 sehingga limbah sudah aman untuk diaplikasikan pada lahan.

\section{Hasil Analisis Tanah}

\section{Sifat Fisika Tanah}

Penentuan sifat fisik tanah dilakukan dengan mengambil sampel tanah untuk melihat bobot isi, porositas, dan permeabilitas tanah. Sampel tanah untuk menentukan tektur tanah diambil pada lahan kontrol, lahan aplikasi dan tanah pada parit pada kedalaman $0-30 \mathrm{~cm}$ dan $30-60 \mathrm{~cm}$. Hasil dari analisis sifat fisika tanah dapat disajikan pada Tabel 2.

Tabel 2. Bobot isi, porositas, dan permeabilitas tanah di lahan kontrol (LK), lahan aplikasi (LA), dan didalam parit (P) sebelum aplikasi LCPKS.

\begin{tabular}{lcccccc}
\hline \multirow{2}{*}{ Parameter } & \multicolumn{6}{c}{ Kedalaman } \\
\cline { 2 - 7 } & \multicolumn{3}{c}{$0-30 \mathrm{~cm}$} & \multicolumn{3}{c}{$30-60 \mathrm{~cm}$} \\
\cline { 2 - 7 } & LK & LA & P & LK & LA & P \\
\hline $\begin{array}{l}\text { Bobot isi } \\
\left(\mathrm{gr} / \mathrm{cm}^{3}\right)\end{array}$ & 1,67 & 1,19 & 1,12 & 1,22 & 1,52 & 1,29 \\
\hline $\begin{array}{l}\text { Porositas } \\
(\%)\end{array}$ & 22,3 & 54,2 & 55,5 & 51,7 & 33,3 & 47,7 \\
& 2 & 3 & 5 & 7 & 3 & 7 \\
\hline $\begin{array}{l}\text { Permeabilit } \\
\begin{array}{l}\text { as } \\
(\mathrm{cm} / \text { jam) }\end{array}\end{array}$ & 2,71 & 3,51 & 7,57 & 1,31 & 2,41 & 3,76 \\
\hline
\end{tabular}

Bobot isi tanah atau disebut juga bobot/volume tanah merupakan kerapatan tanah per satuan volume yang menunjukkan berat tanah kering dengan volume tanah termasuk pori tanah. Dari tabel di atas dapat dilihat bahwa nilai bobot isi dari tanah pada lahan kontrol, lahan aplikasi dan parit memiliki nilai yang hampir sama.

Porositas tanah adalah proporsi ruang yang terdapat dalam satuan volume tanah yang dapat ditempati oleh udara dan air. Dari tabel diatas dapat dilihat bahwa nilai porositas tanah di lahan kontrol pada kedalaman 0-30 cm memiliki nilai rendah sedangkan sisanya memiliki nilai yang sedang.

Permeabilitas merupakan sifat yang paling penting karena dapat mempengaruhi kesuburan tanah. Nilai permeabilitas tanah dikelompokkan menjadi: sangat lambat $(<0,5 \mathrm{~cm} / \mathrm{jam})$, agak lambat $(0,5-2,0 \mathrm{~cm} / \mathrm{jam})$, sedang (2,0-6,25 $\mathrm{cm} / \mathrm{jam})$, agak cepat $(6,25-12,5 \mathrm{~cm} / \mathrm{jam})$, dan cepat $(>12,5 \mathrm{~cm} / \mathrm{jam})$ (Hardjowigeno, 2003). Tabel 3 menunjukkan bahwa nilai permeabilitas tanah adalah sedang dan agak cepat di dalam parit pada kedalaman $0-30 \mathrm{~cm}$. Permeabilitas pada dasarnya adalah kemampuan tanah untuk mengalirkan air. Jika nilai permeabilitas tanahnya cepat maka tanah tersebut mampu mengalirkan air dan bahan organik ke lapisan bawah lebih banyak. Kategori sedang dan agak cepat berarti tanah tersebut cukup baik dalam mengalirkan air.

Berdasarkan hasil penelitian yang dilakukan (Silalahi \& Supijatno, 2017) yang mengkaji dampak LCPKS terhadap sifat fisik tanah pasca aplikasi di perkebunan kelapa sawit Angsana Estate, Kalimantan Selatan (Tabel 14) terdapat perubahan nilai bobot isi, porositas, dan permeabilitas tanah.

Tabel 3. Bobot isi, porositas, dan permeabilitas tanah di lahan kontrol (LK), lahan aplikasi (LA), dan didalam parit (P) setelah aplikasi LCPKS.

\begin{tabular}{lcccccc}
\hline \multirow{2}{*}{ Parameter } & \multicolumn{6}{c}{ Kedalaman } \\
\cline { 2 - 7 } & \multicolumn{3}{c}{$0-30 \mathrm{~cm}$} & \multicolumn{3}{c}{$30-60 \mathrm{~cm}$} \\
\cline { 2 - 7 } & LK & LA & P & LK & LA & P \\
\hline $\begin{array}{l}\text { Bobot isi } \\
(\text { gr/cm }\end{array}$ & 1,48 & 1,86 & 1,59 & 1,56 & 1,62 & 1,76 \\
\hline $\begin{array}{l}\text { Porositas } \\
(\%)\end{array}$ & $\begin{array}{c}36,8 \\
3\end{array}$ & $\begin{array}{c}28,7 \\
5\end{array}$ & $\begin{array}{c}23,4 \\
7\end{array}$ & $\begin{array}{c}29,2 \\
1\end{array}$ & $\begin{array}{c}20,1 \\
7\end{array}$ & $\begin{array}{c}17,8 \\
6\end{array}$ \\
\hline $\begin{array}{l}\text { Permeabilit } \\
\text { as } \\
(\mathrm{cm} / \text { jam })\end{array}$ & 4,08 & 4,16 & 3,18 & 3,12 & 3,04 & 3,02 \\
\hline
\end{tabular}

Sumber : Kantor Besar ASE (2011); Hasil analisa tanah di Lab. PPLH Lembaga Penelitian Universitas Lambung Mangkurat, September 2010. 
Perbandingan sifat fisik tanah dari ketiga lokasi sampling pada kedalaman $0-30 \mathrm{~cm}$ dan 30-60 cm setelah aplikasi LCPKS disajikan pada Gambar 1 dan Gambar 2.

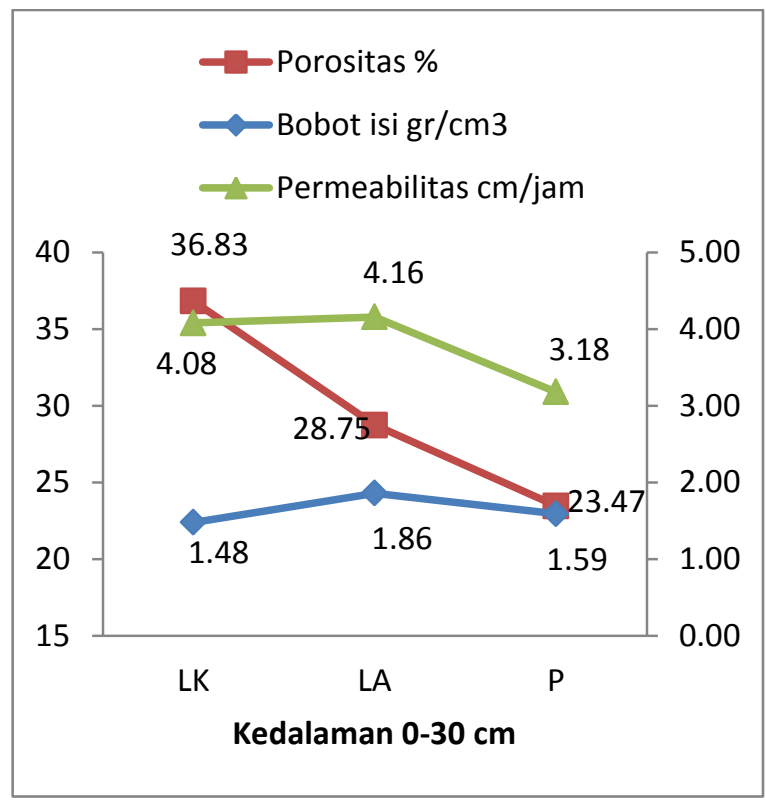

Gambar 1. Grafik Bobot isi, Porositas, dan Permeabilitas tanah setelah aplikasi LCPKS di kedalaman 0-30 cm.

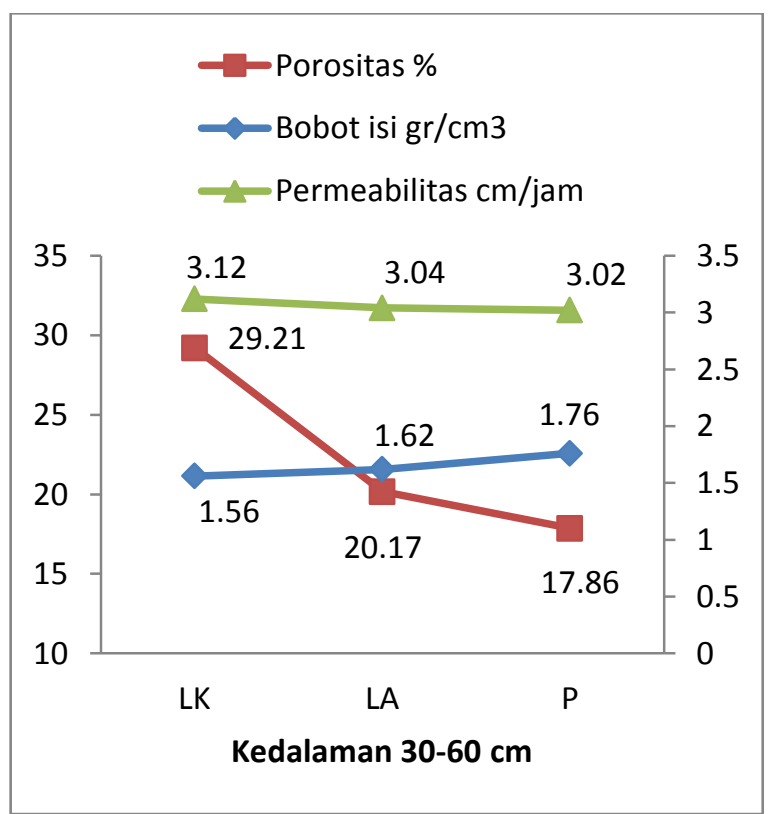

Gambar 2. Grafik Bobot isi, Porositas, dan Permeabilitas tanah setelah aplikasi LCPKS di kedalaman 30$60 \mathrm{~cm}$.
Gambar 2 dan Gambar 3 menunjukkan terjadi penurunan persen porositas tanah pada lahan aplikasi (LA, 28,75\% dan Parit, 23,47\%) dibandingkan dengan tanpa aplikasi ( LK, $36,83 \%$ ) pada kedalaman tanah hingga $30 \mathrm{~cm}$, sementara pada tanah dengan kedalaman yang lebih $(60 \mathrm{~cm})$ persen penurunan tanah hampir sama dengan pada kedalaman $30 \mathrm{~cm}$. Sebaliknya penambahan LCPKS di lahan aplikasi (LA) berdampak pada penambahan bobot isi $\left(1,86 \mathrm{~g} / \mathrm{cm}^{3}\right)$ dan permeabilitas tanah $(4,16 \mathrm{~cm} / \mathrm{jam})$ dibandingkan tanpa LCPKS (LK) $\left(1,48 \mathrm{~g} / \mathrm{cm}^{3}\right.$ dan $\left.4,08 \mathrm{~cm} / \mathrm{jam}\right)$ untuk sampel tanah dikedalaman $30 \mathrm{~cm}$. . Penambahan bahan organik dari aplikasi LCPKS akan meningkatkan bobot isi tanah, yang berarti kemampuan tanah untuk menahan air dan unsur hara akan menjadi lebih baik. LCPKS yang diaplikasikan akan mengisi ruang pori sehingga porositas tanah di lahan aplikasi dan di dalam parit akan lebih tinggi daripada di lahan kontrol. Penurunan nilai porositas masih dalam batas yang normal dan porositas masih dalam kategori baik sehingga penambahan LCPKS tidak mengganggu atau merusak porositas tanah. Sedangkan untuk nilai permeabilitas tanah karena adanya penambahan LCPKS maka nilainya akan turun terutama pada parit. Hal ini dikarenakan LCPKS yng merupakan bahan cair akan membuat tanah di parit lama kelamaan akan jenuh terhadap air sehingga nilai permeabilitasnya turun.

Dampak aplikasi LCPKS terhadap sifat fisik tanah pada lahan perkebunan kelapa sawit milik Angkasa Estate di Kalimantan Selatan diperkirakan akan sama dengan sifat fisik tanah di lahan kelapa sawit milik PT. PMP, Kabupatem Maybrat. Dampak yang terjadi berupa kenaikan bobot isi, dan penurunan porositas dan permeabilitas tanah pada lahan aplikasi dan parit.

Tekstur tanah menunjukkan kasar halusnya tanah yang dinyatakan dalam perbandingan proporsi (\%) antara komposisi partikel-partikel tanah. Sampel tanah untuk menentukan tekstur tanah pada kedalaman 0-20 $\mathrm{cm}, 20-40 \mathrm{~cm}, 40-60 \mathrm{~cm}, 60-80 \mathrm{~cm}, 80-100 \mathrm{~cm}$, dan 100-120 cm. Hasil analisis tektur tanah sebelum aplikasi LCPKS dapat disajikan pada Tabel 3.

Tabel 3. Tekstur tanah pada lahan kontrol (LK), lahan aplikasi (LA), dan didalam parit (P) sebelum aplikasi LCPKS. 


\begin{tabular}{|c|c|c|c|c|c|c|c|}
\hline \multirow{2}{*}{ Lokasi } & \multirow{2}{*}{ Tekstur } & \multicolumn{6}{|c|}{ Kedalaman } \\
\hline & & $0-20$ & $20-40$ & $40-60$ & $60-80$ & $80-100$ & $100-120$ \\
\hline \multirow{3}{*}{ LK } & Pasir & 14,22 & 3,74 & 2,20 & 2,98 & 3,96 & 2,29 \\
\hline & Debu & 44,12 & 33,78 & 32,56 & 32,30 & 34,87 & 52,36 \\
\hline & Liat & 41,66 & 62,48 & 65,24 & 64,72 & 61,17 & 45,35 \\
\hline \multicolumn{2}{|c|}{ Kelas } & $\begin{array}{c}\text { Liat } \\
\text { berdebu }\end{array}$ & Liat & Liat & Liat & Liat & $\begin{array}{c}\text { Liat } \\
\text { berdebu }\end{array}$ \\
\hline \multirow{3}{*}{ LA } & Pasir & 46,08 & 74,70 & 59,68 & 64,78 & 73,97 & 57,32 \\
\hline & Debu & 28,30 & 15,10 & 22,61 & 18,89 & 14,13 & 34,57 \\
\hline & Liat & 25,62 & 10,20 & 17,71 & 16,33 & 11,90 & 8,11 \\
\hline \multicolumn{2}{|c|}{ Kelas } & Lempung & $\begin{array}{l}\text { Lempung } \\
\text { berpasir }\end{array}$ & $\begin{array}{c}\text { Lempung } \\
\text { berpasir }\end{array}$ & $\begin{array}{l}\text { Lempung } \\
\text { berpasir }\end{array}$ & $\begin{array}{l}\text { Lempung } \\
\text { berpasir }\end{array}$ & $\begin{array}{c}\text { Lempung } \\
\text { berpasir }\end{array}$ \\
\hline \multirow{3}{*}{$\mathrm{P}$} & Pasir & 54,07 & 28,44 & 57,68 & 53,32 & 42,23 & 17,73 \\
\hline & Debu & 27,46 & 55,88 & 23,73 & 35,59 & 41,92 & 54,16 \\
\hline & Liat & 18,47 & 15,68 & 18,59 & 11,09 & 15,83 & 28,11 \\
\hline \multicolumn{2}{|c|}{ Kelas } & $\begin{array}{l}\text { Lempung } \\
\text { berpasir }\end{array}$ & $\begin{array}{c}\text { Lempung } \\
\text { berdebu }\end{array}$ & $\begin{array}{l}\text { Lempung } \\
\text { berpasir }\end{array}$ & $\begin{array}{l}\text { Lempung } \\
\text { berpasir }\end{array}$ & Lempung & $\begin{array}{c}\text { Lempung } \\
\text { liat } \\
\text { berdebu }\end{array}$ \\
\hline \multicolumn{4}{|c|}{$\begin{array}{l}\text { Dari tabel diatas dapat dilihat bahwa } \\
\text { tekstur tanah pada lahan kontrol rata-rata } \\
\text { adalah liat berdebu, pada lahan aplikasi adalah } \\
\text { lempung berpasir dan pada parit adalah antara } \\
\text { lempung berpasir dan lempung berdebu. }\end{array}$} & \multicolumn{4}{|c|}{$\begin{array}{l}\text { terutama pada tanah bagian permukaan (pada } \\
\text { kedalaman 0-30 cm). Hal ini disebabkan } \\
\text { karena adanya penambahan bahan organik. } \\
\text { Tekstur tanah pada lahan aplikasi dan parit } \\
\text { pada kedalalaman } 0-20 \mathrm{~cm} \text { dan } 20-40 \mathrm{~cm} \\
\text { termasuk kelas berliat (halus) sedangkan di } \\
\text { lahan kontrol pada kedalaman yang sama } \\
\text { termasuk dalam lempung berliat (Tabel 4). }\end{array}$} \\
\hline
\end{tabular}

ke lahan akan memperbaiki tekstur tanah

Tabel 4. Tekstur tanah pada lahan kontrol (LK), lahan aplikasi (LA), dan didalam parit (P) setelah aplikasi LCPKS.

\begin{tabular}{|c|c|c|c|c|c|c|c|}
\hline \multirow{2}{*}{ Lokasi } & \multirow{2}{*}{ Tekstur } & \multicolumn{6}{|c|}{ Kedalaman } \\
\hline & & $0-20$ & $20-40$ & $40-60$ & $60-80$ & $80-100$ & $100-120$ \\
\hline \multirow{3}{*}{ LK } & Pasir & 39,71 & 39,92 & 30,29 & 28,98 & 23,72 & 27,52 \\
\hline & Debu & 29,49 & 27,17 & 26,96 & 26,09 & 24,19 & 24,92 \\
\hline & Liat & 30,8 & 32,91 & 42,75 & 44.93 & 52,07 & 47,56 \\
\hline \multicolumn{2}{|c|}{ Kelas } & $\begin{array}{c}\text { Lempung } \\
\text { berliat }\end{array}$ & $\begin{array}{c}\text { Lempung } \\
\text { berliat }\end{array}$ & $\begin{array}{l}\text { Berliat } \\
\text { (Halus) }\end{array}$ & $\begin{array}{l}\text { Berliat } \\
\text { (Halus) }\end{array}$ & $\begin{array}{l}\text { Berliat } \\
\text { (Halus) }\end{array}$ & $\begin{array}{l}\text { Berliat } \\
\text { (Halus) }\end{array}$ \\
\hline \multirow{3}{*}{ LA } & Pasir & 31,28 & 43,62 & 32,01 & 29,38 & 38 & 48,12 \\
\hline & Debu & 38,88 & 11,9 & 30,39 & 27,32 & 21,32 & 15,86 \\
\hline & Liat & 29,84 & 44,48 & 42,6 & 43,3 & 40,68 & 36,02 \\
\hline \multicolumn{2}{|c|}{ Kelas } & $\begin{array}{c}\text { Lempung } \\
\text { berliat }\end{array}$ & $\begin{array}{l}\text { Berliat } \\
\text { (Halus) }\end{array}$ & $\begin{array}{l}\text { Berliat } \\
\text { (Halus) }\end{array}$ & $\begin{array}{l}\text { Berliat } \\
\text { (Halus) }\end{array}$ & $\begin{array}{l}\text { Berliat } \\
\text { (Halus) }\end{array}$ & $\begin{array}{l}\text { Berliat } \\
\text { (Halus) }\end{array}$ \\
\hline \multirow{3}{*}{$\mathrm{P}$} & Pasir & 27,11 & 25,44 & 23,13 & 27,36 & 20,99 & 43,11 \\
\hline & Debu & 32,61 & 25,64 & 25,4 & 23,93 & 28,37 & 17,15 \\
\hline & Liat & 40,28 & 48,92 & 51,48 & 48,71 & 50,64 & 39,74 \\
\hline \multicolumn{2}{|c|}{ Kelas } & $\begin{array}{l}\text { Berliat } \\
\text { (Halus) }\end{array}$ & $\begin{array}{l}\text { Berliat } \\
\text { (Halus) }\end{array}$ & $\begin{array}{l}\text { Berliat } \\
\text { (Halus) }\end{array}$ & $\begin{array}{l}\text { Berliat } \\
\text { (Halus) }\end{array}$ & $\begin{array}{l}\text { Berliat } \\
\text { (Halus) }\end{array}$ & $\begin{array}{l}\text { Berliat } \\
\text { (Halus) }\end{array}$ \\
\hline
\end{tabular}




\section{Sifat Kimia Tanah}

Sampel tanah untuk menentuan sifat kimia tanah diambil pada tiga lokasi yaitu lahan kontrol (LK), lahan aplikasi (LA), dan di dalam parit $(\mathrm{P})$ pada kedalaman $0-20 \mathrm{~cm}, 20-40$ $\mathrm{cm}, 40-60 \mathrm{~cm}, 60-80 \mathrm{~cm}, 80-100 \mathrm{~cm}$, dan $100-$ $120 \mathrm{~cm}$. Hasil dari analisis sifat kimia tanah dapat ditunjukkan pada Tabel 5.

Tabel 5. Sifat kimia tanah pada berbagai kedalaman di lahan kontrol (LK), lahan aplikasi (LA), dan di dalam parit (P) sebelum aplikasi LCPKS.

\begin{tabular}{|c|c|c|c|c|c|c|c|c|c|c|}
\hline $\begin{array}{c}\text { Kode } \\
\text { Sampel }\end{array}$ & $\mathrm{pH}$ & $\mathrm{C}$ & $\mathrm{N}$ & $\mathrm{P}$ & $\mathrm{Ca}$ & $\mathrm{Mg}$ & $\mathrm{K}$ & $\mathrm{Na}$ & KTK & KB \\
\hline & & \multicolumn{2}{|c|}{$(\%)$} & $(\mathrm{mg} / \mathrm{kg})$ & \multicolumn{5}{|c|}{$(\mathrm{me} / 100 \mathrm{~g})$} & $(\%)$ \\
\hline \multicolumn{11}{|c|}{ LK } \\
\hline $0-20$ & 4,05 & 0,55 & 0,04 & 1,55 & 0,17 & 0,05 & 0,20 & 0,04 & 4,58 & 10,04 \\
\hline $20-40$ & 4,28 & 0,30 & 0,07 & 8,08 & 0,21 & 0,06 & 0,22 & 0,07 & 9,78 & 5,73 \\
\hline $40-60$ & 4,76 & 0,39 & 0,10 & 0,23 & 0,22 & 0,06 & 0,21 & 0,06 & 2,28 & 19,50 \\
\hline $60-80$ & 4,48 & 0,54 & 0,05 & 4,35 & 0,20 & 0,05 & 0,20 & 0,05 & 8,88 & 5,63 \\
\hline $80-100$ & 4,53 & 0,15 & 0,11 & 0,82 & 0,24 & 0,07 & 0,18 & 0,06 & 4,86 & 11,31 \\
\hline $100-120$ & 4,58 & 0,22 & 0,06 & 2,78 & 0,15 & 0,04 & 0,16 & 0,04 & 5,83 & 6,69 \\
\hline \multicolumn{11}{|c|}{ LA } \\
\hline $0-20$ & 4,31 & 5,22 & 0,23 & 32,26 & 0,16 & 0,06 & 0,21 & 0,04 & 6,74 & 6,98 \\
\hline $20-40$ & 4,45 & 1,91 & 0,05 & 6,60 & 0,20 & 0,06 & 0,16 & 0,05 & 2,80 & 16,77 \\
\hline $40-60$ & 4,16 & 2,17 & 0,10 & 8,08 & 0,09 & 0,03 & 0,19 & 0,03 & 4,15 & 8,19 \\
\hline $60-80$ & 4,40 & 2,69 & 0,13 & 8,14 & 0,09 & 0,03 & 0,19 & 0,03 & 4,07 & 8,35 \\
\hline $80-100$ & 3,87 & 1,07 & 0,02 & 4,65 & 0,09 & 0,02 & 0,21 & 0,02 & 2,22 & 15,30 \\
\hline $100-120$ & 4,32 & 4,06 & 0,18 & 17,15 & 0,09 & 0,03 & 0,19 & 0,02 & 4,73 & 6,97 \\
\hline \multicolumn{11}{|c|}{$\mathrm{P}$} \\
\hline $0-20$ & 4,27 & 2,24 & 0,09 & 5,80 & 0,23 & 0,07 & 0,18 & 0,05 & 4,36 & 12,15 \\
\hline $20-40$ & 4,04 & 6,12 & 0,19 & 13,39 & 0,19 & 0,08 & 0,21 & 0,04 & 3,89 & 13,37 \\
\hline $40-60$ & 4,21 & 2,65 & 0,13 & 2,44 & 0,19 & 0,06 & 0,18 & 0,04 & 2,47 & 19,04 \\
\hline $60-80$ & 4,70 & 2,24 & 0,16 & 3,54 & 0,15 & 0,05 & 0,19 & 0,03 & 4,33 & 9,69 \\
\hline $80-100$ & 4,66 & 0,23 & 0,04 & 3,10 & 0,15 & 0,06 & 0,21 & 0,05 & 2,42 & 19,45 \\
\hline $100-120$ & 4,28 & 8,13 & 0,29 & 19,41 & 0,23 & 0,08 & 0,23 & 0,06 & 5,53 & 10,85 \\
\hline $\begin{array}{l}\text { Dari } \\
\text { nilai pH } \\
\text { nilai yan } \\
\text { dalam ka } \\
\text { organik s } \\
\text { dalam kat }\end{array}$ & asil y & g dip & oleh & hat bah & \multicolumn{6}{|c|}{$\begin{array}{l}\text { Berdasarkan hasil penelitian yang } \\
\text { dilakukan Silalahi dan Supijatno (2017), di } \\
\text { perkebunan kelapa sawit Angsana Estate, } \\
\text { Kalimantan Selatan hasil analisis tanah setelah } \\
\text { aplikasi LCPKS di lahan aplikasi seperti yang } \\
\text { tertera pada Tabel } 6 \text {. }\end{array}$} \\
\hline
\end{tabular}
seperti $\mathrm{Ca}, \mathrm{Mg}, \mathrm{K}$ dan $\mathrm{Na}$ juga dalam kategori yang sangat rendah. Sedangkan untuk nilai kapasitas tukar kationnya berada dalam kategori sangat rendah sampai rendah.

Tabel 6. Sifat kimia tanah pada berbagai kedalaman di lahan kontrol (LK), lahan aplikasi (LA), dan di dalam parit (P) setelah aplikasi LCPKS.

\begin{tabular}{llcccccccc}
\hline $\begin{array}{c}\text { Kode } \\
\text { Sampel }\end{array}$ & $\mathrm{pH}$ & $\mathrm{C}$ & $\mathrm{N}$ & \multicolumn{1}{c}{$\mathrm{P}$} & $\mathrm{Ca}$ & $\mathrm{Mg}$ & $\mathrm{K}$ & $\mathrm{Na}$ & $\mathrm{KTK}$ \\
\hline \multicolumn{8}{c}{$(\%)$} & \multicolumn{10}{c}{$\mathrm{LK} / \mathrm{kg})$} \\
\hline $0-20$ & $4.47) 1$ & $4.35) 4$ & $0.55) 4$ & $8.62) 1$ & $0.2) 1$ & $0.1) 1$ & $0.76) 4$ & $0.77) 4$ & $13.83) 2$ \\
$20-40$ & $4.4) 1$ & $3.25) 4$ & $0.51) 4$ & $15.81) 2$ & $0.1) 1$ & $0.1) 1$ & $0.58) 3$ & $0.73) 4$ & $11.95) 2$ \\
$40-60$ & $4.39) 1$ & $3.82) 4$ & $0.56) 4$ & $15.09) 2$ & $0.42) 1$ & $0.11) 1$ & $0.51) 3$ & $0.47) 3$ & $13.62) 2$
\end{tabular}




\begin{tabular}{|c|c|c|c|c|c|c|c|c|c|}
\hline $60-80$ & 4.77)1 & 3.67)4 & $0.4) 3$ & 11.81)2 & $0.21) 1$ & $0.21) 1$ & $0.4) 3$ & $0.51) 3$ & $19.03) 3$ \\
\hline 80-100 & 4.29)1 & $3.97) 4$ & $0.47) 3$ & 5.93)1 & $0.11) 1$ & $0.11) 1$ & $0.48) 3$ & $0.48) 3$ & $17.8) 3$ \\
\hline $100-120$ & 4.36)1 & $3.45) 4$ & $0.4) 3$ & 15.21)2 & $0.11) 1$ & $0.11) 1$ & $0.56) 3$ & $0.56) 3$ & 20)3 \\
\hline \multicolumn{10}{|c|}{ LA } \\
\hline $0-20$ & 4.9)1 & 5.38)5 & $0.58) 4$ & 14.74)2 & $1.35) 1$ & $0.1) 1$ & $0.85) 4$ & 0.91)4 & $20.68) 3$ \\
\hline $20-40$ & $4.48) 1$ & $3.95) 4$ & $0.54) 4$ & 11.58)2 & $0.1) 1$ & $0.2) 1$ & $0.52) 3$ & $0.68) 3$ & $23.31) 3$ \\
\hline $40-60$ & 4.54)1 & $3.33) 4$ & $0.59) 4$ & 14.67)2 & $0.21) 1$ & $0.21) 1$ & $1.28) 5$ & $1.09) 5$ & $35.36) 4$ \\
\hline $60-80$ & $4.58) 1$ & $3.31) 4$ & $0.37) 3$ & $5.84) 1$ & $0.21) 1$ & $0.21) 1$ & $0.51) 3$ & $0.65) 3$ & $20.5) 3$ \\
\hline 80-100 & $4.53) 1$ & $3.54) 4$ & $0.51) 4$ & $5.74) 1$ & $0.52) 1$ & $0.52) 2$ & $0.47) 3$ & $0.46) 3$ & $23.38) 3$ \\
\hline $100-120$ & $4.54) 1$ & $3.64) 4$ & $0.46) 3$ & $8.85) 1$ & $0.11) 1$ & $0.11) 1$ & $0.54) 3$ & $0.51) 3$ & $18.59) 3$ \\
\hline \multicolumn{10}{|c|}{$\mathrm{P}$} \\
\hline $0-20$ & $6.59) 3$ & $5.05) 5$ & $0.49) 3$ & $20.75) 3$ & $1.33) 1$ & $0.21) 1$ & $0.42) 3$ & $2.56) 5$ & $29.85) 4$ \\
\hline $20-40$ & $5.01) 1$ & $3.73) 4$ & $0.64) 3$ & $18.73) 3$ & $0.93) 1$ & $0.1) 1$ & $2.18) 5$ & $1.91) 5$ & $17.45) 3$ \\
\hline $40-60$ & 4.5)1 & $3.79) 4$ & $0.47) 3$ & 21.09)3 & $0.73) 1$ & $0.42) 2$ & 2.09)5 & $1.74) 5$ & $22.53) 3$ \\
\hline $60-80$ & 4.87)1 & $3.62) 4$ & $0.42) 3$ & 11.85)2 & $1.05) 1$ & $0.84) 2$ & $2.17) 5$ & $2.29) 5$ & $41.76) 5$ \\
\hline $80-100$ & $4.82) 1$ & $3.78) 4$ & $0.4) 3$ & 11.88)2 & $0.52) 1$ & $1.26) 3$ & $0.56) 3$ & $2.06) 5$ & $21.12) 3$ \\
\hline $100-120$ & $4.53) 1$ & $3.84) 4$ & $0.56) 4$ & $8.82) 1$ & $0.52) 1$ & $0.1) 1$ & $1.05) 5$ & $1.1) 5$ & $18.35) 3$ \\
\hline
\end{tabular}

Sumber : Kantor Besar ASE (2011); Hasil analisa tanah di Lab. PPLH Lembaga Penelitian Universitas Lambung Mangkurat, September 2010.

Keterangan : )1sangat rendah; )2rendah; )3sedang; )4tinggi; )5sangat tinggi (Berdasarkan kriteria sifat-sifat kimia tanah) (Hardjowigeno \& Widiatmaka, 2001)

Data pada Tabel 6 menunjukkan bahwa setelah penambahan LCPKS nilai $\mathrm{pH}$ pada Lahan kontrol, lahan aplikasi, dan di dalam parit relatif sama yaitu pada kisaran sangat asam $(\mathrm{pH}<4,4)$ sampai agak masam $(\mathrm{pH} \mathrm{5,6-}$ $6,5)$, tetapi $\mathrm{pH}$ pada parit di kedalaman $0-20 \mathrm{~cm}$ mendekati netral yaitu 6,59. Kandungan COrganik dan N-total pada lahan kontrol, lahan aplikasi dan dalam parit di setiap kedalaman menunjukkan nilai yang relatif sama yaitu pada kisaran sedang-tinggi kecuali kandungan Corganik di lahan aplikasi dan dalam parit pada kedalaman 0-20 cm yang termasuk sangat tinggi. Hal ini menunjukkan bahwa aplikasi LCPKS menambah ketersediaan kandungan bahan organik (C organik dan nitrogen) pada tanah bagian permukaan. Sedangkan untuk nilai P-tersedia paling tinggi terlihat pada kedalaman 0-20 $\mathrm{cm}$ dan 20-40 $\mathrm{cm}$ didalam parit.

Aplikasi limbah cair ke lahan perkebunan memberikan pengaruh positif dalam meningkatkan kesuburan tanah, terlihat dari peningkatan kandungan konsentrasi kationkation basa dapat tukar dalam tanah. Jumlah kation-kation basa berhubungan erat dengan $\mathrm{pH}$ tanah, dimana tanah dengan $\mathrm{pH}$ rendah umumnya mempunyai jumlah kation-kation basa rendah dan sebaliknya tanah dengan $\mathrm{pH}$ tinggi mempunyai jumlah kation-kation basa tinggi ( (Hardjowigeno, 2003). Pada Tabel 6 terlihat bahwa kandungan unsur $\mathrm{Mg}, \mathrm{Na}$, dan $\mathrm{K}$ pada lahan aplikasi dan dalam parit lebih baik dibandingkan lahan kontrol sedangkan kandungan $\mathrm{Ca}$ relatif sama hampir setiap kedalaman.

Kapasitas tukar kation (KTK) merupakan sifat kimia yang berhubungan erat dengan kesuburan tanah. Tanah dengan KTK tinggi mampu menyerap dan menyediakan unsur hara lebih baik. Tanah dengan KTK tinggi didominasi oleh kation-kation basa $(\mathrm{Ca}, \mathrm{Mg}$, $\mathrm{Na}, \mathrm{K})$ dapat meningkatkan kesuburan tanah, (Hardjowigeno, 2003). Aplikasi limbah cair berperan dalam memperbaiki KTK tanah. Hal ini terlihat dari nilai KTK tanah di lahan aplikasi dan dalam flat bed relatif lebih baik dibandingkan di lahan kontrol (Tabel 6).

Pengambilan sampel tanah juga dilakukan untuk menganalisa beberapa jenis logam berat yang terdapat dalam tanah yaitu $\mathrm{Pb}, \mathrm{Cu}, \mathrm{Cd}$, dan $\mathrm{Zn}$. Tembaga $(\mathrm{Cu})$ dan seng ( $\mathrm{Zn})$ merupakan unsur mikro yang dibutuhkan tanaman. Tembaga (dalam bentuk kation $\mathrm{Cu}^{2+}$ ) bagi tanaman berperan dalam penyusunan enzim dan pembentukan klorofil, Seng (dalam bentuk kation $\mathrm{Zn}^{2+}$ ) berperan dalam pembentukan hormon pertumbuhan dan katalis 
dalam pembentukan protein (Hardjowigeno, 2003). Hasil analisis logam berat pada tanah sebelum aplikasi LCPKS dapat dilihat pada tabel berikut:

Tabel 7. Kandungan Logam berat pada sampel tanah pada berbagai kedalaman di lahan kontrol, lahan aplikasi dan dalam parit sebelum aplikasi LCPKS.

\begin{tabular}{|c|c|c|c|c|c|c|c|}
\hline \multirow{2}{*}{$\begin{array}{c}\text { Logam } \\
\text { Berat }\end{array}$} & \multirow{2}{*}{$\begin{array}{l}\text { Lokasi } \\
\text { sampel }\end{array}$} & \multicolumn{6}{|c|}{ Kedalaman } \\
\hline & & $0-20$ & $20-40$ & $40-60$ & $60-80$ & $80-100$ & $100-120$ \\
\hline \multirow{3}{*}{$\begin{array}{c}\mathrm{Pb} \\
(\mathrm{mg} / \mathrm{kg})\end{array}$} & LK & 8 & 6 & 10 & 6 & 8 & 8 \\
\hline & LA & $<5$ & $<5$ & 12 & 6 & 11 & 7 \\
\hline & $\mathrm{P}$ & $<5$ & 7 & $<5$ & $<5$ & $<5$ & $<5$ \\
\hline \multirow{3}{*}{$\begin{array}{c}\mathrm{Cu} \\
(\mathrm{mg} / \mathrm{kg})\end{array}$} & LK & 2 & $<2$ & 3 & $<2$ & $<2$ & 3 \\
\hline & LA & 2 & $<2$ & 4 & 3 & 4 & 3 \\
\hline & $\mathrm{P}$ & 2 & 3 & $<2$ & $<2$ & $<2$ & 3 \\
\hline \multirow{3}{*}{$\begin{array}{c}\mathrm{Cd} \\
(\mathrm{mg} / \mathrm{kg})\end{array}$} & $\begin{array}{l}\mathrm{LK} \\
\end{array}$ & $<0,5$ & $<0,5$ & $<0,5$ & $<0,5$ & $<0,5$ & $<0,5$ \\
\hline & LA & $<0,5$ & $<0,5$ & $<0,5$ & $<0,5$ & $<0,5$ & $<0,5$ \\
\hline & $\mathrm{P}$ & $<0,5$ & $<0,5$ & $<0,5$ & $<0,5$ & $<0,5$ & $<0,5$ \\
\hline \multirow{3}{*}{$\begin{array}{c}\mathrm{Zn} \\
(\mathrm{mg} / \mathrm{kg})\end{array}$} & LK & 4 & 3 & 3 & 3 & 3 & 3 \\
\hline & LA & 3 & 1 & 2 & 2 & 2 & 2 \\
\hline & $\mathrm{P}$ & 4 & 2 & 2 & 2 & 3 & 3 \\
\hline \multicolumn{4}{|c|}{$\begin{array}{l}\text { Dari tabel diatas dapat dilihat bahwa } \\
\text { kandungan logm berat } \mathrm{Pb}, \mathrm{Cu}, \mathrm{Cd} \text {, dan } \mathrm{Zn} \\
\text { dalam tanah tergolong rendah. Nilai } \mathrm{Cd} \\
\text { memiliki nilai yang sangat rendah yaitu }<0,5 \\
\mathrm{mg} / \mathrm{kg} \text { di semua lokasi pengambilan sampel } \\
\text { dari lahan kontrol, lahan aplikasi dan di dalam } \\
\text { parit. Untuk nilai } \mathrm{Pb}, \mathrm{Cu} \text {, dan } \mathrm{Zn} \text { juga memiliki } \\
\text { nilai yang hampir sama di semua lokasi. }\end{array}$} & \multirow{2}{*}{\multicolumn{4}{|c|}{$\begin{array}{l}\text { Berdasarkan hasil penelitian yang } \\
\text { dilakukan Silalahi dan Supijatno (2017), di } \\
\text { perkebunan kelapa sawit Angsana Estate, } \\
\text { Kalimantan Selatan hasil analisis tanah setelah } \\
\text { aplikasi LCPKS di lahan aplikasi seperti yang } \\
\text { tertera pada tabel berikut: } \\
\text { kedalaman di lahan kontrol, lahan aplikasi dan }\end{array}$}} \\
\hline \multicolumn{4}{|c|}{$\begin{array}{l}\text { Tabel 8. Kandungan Logam berat pada berbagai kedalaman di lahan kontrol, lahan aplikasi dan } \\
\text { dalam parit setelah aplikasi LCPKS. }\end{array}$} & & & & \\
\hline \multirow{2}{*}{$\begin{array}{c}\text { Logam } \\
\text { Berat }\end{array}$} & \multirow{2}{*}{$\begin{array}{l}\text { Lokasi } \\
\text { sampel }\end{array}$} & \multicolumn{6}{|c|}{ Kedalaman } \\
\hline & & $0-20$ & $20-40$ & $40-60$ & $60-80$ & $80-100$ & $100-120$ \\
\hline \multirow{3}{*}{$\begin{array}{c}\mathrm{Pb} \\
(\mathrm{mg} / \mathrm{g})\end{array}$} & LK & 0.0741 & 0.0725 & 0.0183 & 0.0696 & 0.0538 & 0.0349 \\
\hline & LA & 0.0391 & 0.0025 & 0.0017 & 0.0018 & 0.0048 & 0.0064 \\
\hline & $\mathrm{P}$ & 0.0055 & 0.0012 & 0.0029 & 0.0052 & 0.0052 & 0.0053 \\
\hline \multirow{3}{*}{$\begin{array}{c}\mathrm{Cu} \\
(\mathrm{mg} / \mathrm{g})\end{array}$} & LK & 3.956 & 3.936 & 3.769 & 3.921 & 3.911 & 2.147 \\
\hline & LA & 0.2003 & 0.0356 & 0.0393 & 0.0324 & 0.2716 & 0.0848 \\
\hline & $\mathrm{P}$ & 0.0159 & 0.0216 & 0.0153 & 0.0222 & 0.0356 & 0.0358 \\
\hline $\mathrm{Cd}$ & LK & 0.0326 & 0.0326 & 0.0081 & 0.0272 & 0.0195 & 0.0012 \\
\hline
\end{tabular}




\begin{tabular}{cccccccc}
$(\mathrm{mg} / \mathrm{g})$ & LA & 0.0015 & 0.001 & 0.0016 & 0.0019 & 0.0021 & 0.001 \\
& $\mathrm{P}$ & 0.0029 & 0.0003 & 0.0017 & 0.0012 & 0.021 & 0.0039 \\
\hline $\mathrm{Zn}$ & LK & 0.8233 & 0.8185 & 0.8009 & 0.8203 & 0.8177 & 0.7549 \\
$(\mathrm{mg} / \mathrm{g})$ & LA & 0.6033 & 0.2479 & 0.1781 & 0.1718 & 0.6003 & 0.3367 \\
& $\mathrm{P}$ & 0.08 & 0.119 & 0.0687 & 0.0953 & 0.1504 & 0.1429 \\
\hline
\end{tabular}

Sumber : Kantor Besar ASE (2011); Hasil analisa tanah di Lab. PPLH Lembaga Penelitian Universitas Lambung Mangkurat, September 2010.

Dari tabel diatas dapat dilihat bahwa, Kandungan logam berat $(\mathrm{Pb}, \mathrm{Cu}, \mathrm{Cd}$, dan $\mathrm{Zn})$ pada lahan kontrol terlihat lebih tinggi dibandingkan pada lahan aplikasi dan dalam parit untuk setiap kedalaman (Tabel 19). Hal ini disebabkan karena di lahan aplikasi dan dalam parit terjadi ikatan kompleks organik yang membentuk khelat, yaitu ikatan antara kation logam dengan bahan organik dalam struktur cincin (Hardjowigeno, 2003). Ikatan ini menyebabkan kation-kation logam tersebut terlindungi oleh bahan organik dan dalam reaksi kimia tidak berfungsi lagi sebagai kation, sehingga ketersediaannya pada lahan aplikasi dan dalam parit menjadi lebih rendah dibandingkan dengan di lahan kontrol.

\section{Hasil Analisis Unsur Hara Tanaman Kelapa Sawit}

Analisis pengaruh aplikasi LCPKS terhadap tanaman dilakukan dengan membandingkan kadar unsur hara pada daun kelapa sawit yang terdapat di lahan aplikasi dan lahan kontrol. Hasil analisis unsur hara pada lahan kontrol dan lahan aplikasi sebelum penambahan LCPKS dapat dilihat pada tabel berikut:

Tabel 9. Hasil analisa daun kelapa sawit pada lahan kontrol dan lahan aplikasi sebelum penambahan LCPKS.

\begin{tabular}{cccc}
\hline $\begin{array}{c}\text { Kandungan Hara dalam } \\
\text { Daun }\end{array}$ & Satuan & $\begin{array}{c}\text { Lahan Aplikasi } \\
(\text { LA })\end{array}$ & $\begin{array}{c}\text { Lahan Kontrol } \\
(\text { LK })\end{array}$ \\
\hline C-Organik & $\%$ & 54,67 & 53,24 \\
N-total & $\%$ & 2,43 & 2,33 \\
$\mathrm{Ca}$ & $\mathrm{mg} / \mathrm{kg}$ & 0,62 & 0,65 \\
$\mathrm{Mg}$ & $\mathrm{mg} / \mathrm{kg}$ & 0,21 & 0,20 \\
$\mathrm{~K}$ & $\%$ & 0,78 & 0,77 \\
$\mathrm{Cu}$ & $\mathrm{mg} / \mathrm{kg}$ & 8,36 & 11,86 \\
$\mathrm{Zn}$ & $\mathrm{mg} / \mathrm{kg}$ & 28,90 & 34,92 \\
$\mathrm{P}$ & $\%$ & 0,12 & 0,13 \\
$\mathrm{Fe}$ & $\mathrm{mg} / \mathrm{kg}$ & 231,32 & 190,20 \\
$\mathrm{Mn}$ & $\mathrm{mg} / \mathrm{kg}$ & 655,43 & 569,27 \\
$\mathrm{~B}$ & $\mathrm{mg} / \mathrm{kg}$ & 15,12 & 24,02 \\
$\mathrm{~S}$ & $\mathrm{mg} / \mathrm{kg}$ & 0,19 & 0,26
\end{tabular}

\footnotetext{
Dari tabel diatas dapat dilihat bahwa lahan kontrol dan lahan aplikasi relatif sama kandungan hara dalam daun kelapa sawit di dan tergolong baik. Kandungan C-Organik
} 
pada daun memiliki nilai yang tinggi $<50 \%$.

Sedangkan nilai $\mathrm{N}$ total berada pada kisaran yang sedang. Sementara untuk nilai Fe dan Mn tergolong cukup tinggi.
Berdasarkan penelitian yang dilakukan (Saputra, 2017), dimana nilai serapan N, P, dan $\mathrm{K}$ pada daun kelapa sawit di lahan aplikasi dan lahan kontrol setelah aplikasi LCPKS disandingkan seperti pada Tabel 10.

Tabel 10. Hasil analisis serapan unsur hara N, P, dan K pada daun kelapa sawit setelah aplikasi LCPKS.

\begin{tabular}{|c|c|c|c|c|c|c|c|c|c|}
\hline & \multicolumn{8}{|c|}{ Serapan Hara } & \multirow{2}{*}{$\begin{array}{l}\text { Rata- } \\
\text { rata }\end{array}$} \\
\hline Sampel & 1 & 2 & 3 & 4 & 5 & 6 & 7 & 8 & \\
\hline \multicolumn{10}{|c|}{$\mathrm{N}$} \\
\hline LA & 2,69 o & $2,83 \mathrm{o}$ & 2,69 o & $2,94 \mathrm{o}$ & $2,72 \mathrm{o}$ & $2,94 \mathrm{o}$ & $2,80 \mathrm{o}$ & $2,86 \mathrm{o}$ & $2,80 \mathrm{o}$ \\
\hline LK & $2,91 \mathrm{o}$ & $2,97 \mathrm{o}$ & $2,50 \mathrm{o}$ & $3,02 \mathrm{~b}$ & $2,75 \mathrm{o}$ & $2,66 \mathrm{o}$ & $2,94 \mathrm{o}$ & $2,66 \mathrm{o}$ & $2,80 \mathrm{o}$ \\
\hline \multicolumn{10}{|c|}{$\mathrm{P}$} \\
\hline LA & 0,15 o & 0,18 o & 0,17 o & 0,16 o & 0,16 o & 0,17 o & 0,17 o & 0,16 o & 0,16 o \\
\hline LK & 0,20 o & 0,18 o & 0,16 o & 0,18 o & $0,17 \mathrm{o}$ & 0,18 o & 0,17 o & 0,17 o & 0,17 o \\
\hline \multicolumn{10}{|c|}{ K } \\
\hline LA & $1,12 \mathrm{o}$ & 1,160 & 0,93 o & $1,00 \mathrm{o}$ & $0,86 \mathrm{~d}$ & $1,22 \mathrm{~b}$ & $0,85 \mathrm{~d}$ & $0,89 \mathrm{~d}$ & $1,00 \mathrm{o}$ \\
\hline LK & $1,17 \mathrm{o}$ & $1,14 \mathrm{o}$ & $0,81 \mathrm{~d}$ & $1,01 \mathrm{o}$ & $0,88 \mathrm{~d}$ & 0,91 o & $0,86 \mathrm{~d}$ & $0,85 \mathrm{~d}$ & 0,95 o \\
\hline
\end{tabular}

Keterangan: $\mathrm{d}=$ kondisi hara defisiensi; $\mathrm{o}=$ kondisi hara optimum; $\mathrm{b}=$ berlebihan

Dari tabel diatas dapat dilihat bahwa bahwa serapan unsur hara Nitrogen pada daun tanaman di areal aplikasi LCPKS relatif sama dengan serapan $\mathrm{N}$ pada areal tanpa aplikasi LCPKS dengan serapan kategori optimum, artinya bahwa tanaman tidak mengalami kekurangan unsur hara N. Rataan serapan unsur hara $\mathrm{N}$ pada areal aplikasi LCPKS adalah $2,808 \%$ dan tanpa aplikasi LCPKS adalah $2,801 \%$. Tidak terdapatnya perbedaan serapan hara $\mathrm{N}$ diduga karena hara $\mathrm{N}$ didalam tanah cukup untuk kebutuhan tanaman.

Kandungan unsur hara Fosfor pada daun tanaman kelapa sawit pada Tabel 22 menunjukkan bahwa pada lahan aplikasi LCPKS dengan kandungan $\mathrm{P}$ 0,165\% relatif sama dengan lahan kontrol yaitu mengandung $\mathrm{P}$ $0,176 \%$ yang dikategorikan optimum artinya tanaman tidak mengalami kekurangan unsur hara P. Pada Tabel 22 terlihat bahwa kadar serapan unsur hara Kalium pada daun tanaman di lahan aplikasi lebih tinggi dari pada lahan kontrol dengan rataan kandungan $\mathrm{K}$ pada areal aplikasi $1,003 \%$ dan tanpa aplikasi $0,953 \%$.
Hasil analisis unsur hara N, P dan K pada daun tanaman kelapa sawit menunjukkan bahwa unsur-unsur tersebut pada tanaman kelapa sawit di lahan aplikasi dan lahan kontrol dalam kondisi optimum. Tetapi, dapat dilihat dari tabel bahwa unsur hara $\mathrm{N}$ dan $\mathrm{K}$ lebih tinggi kandungannya pada lahan aplikasi dibandingkan pada lahan kontrol sedangkan untuk unsur hara $\mathrm{P}$ terlihat lebih tinggi kandungan unsur haranya pada lahan kontrol dibandingkan pada lahan aplikasi. Bila ditinjau dari dari aspek kecukupan kadar hara tanaman, tampak bahwa N, P dan K dikategorikan cukup akan unsur hara.

\section{KESIMPULAN}

Berdasarkan hasil penelitian dapat disimpulkan bahwa nilai kadar LCPKS pada kolam akhir IPAL yang nantinya akan di aplikasikan ke lahan mengalami penurunan kadar yang cukup signifikan sehingga aman untuk di aplikasikan ke lahan. Umumnya setelah aplikasi LCPKS ke lahan akan 
meningkatkan nilai bobot isi serta menurunkan nilai porositas tanah dan permeabilitas tanah. Penambahan bahan organik juga dapat memperbaiki tekstur tanah, terutama pada tanah bagian permukaan (kedalaman 0-30 cm). Aplikasi limbah cair ke lahan perkebunan memberikan pengaruh positif dalam meningkatkan kesuburan tanah, terlihat dari peningkatan kandungan konsentrasi bahan organik dan kation-kation basa dapat tukar dalam tanah.

Berdasarkan hasil analisis unsur hara pada daun kelapa sawit, LCPKS pada lahan kelapa sawit cenderung meningkatkan kadar unsur hara pada daun kelapa sawit dibandingkan dengan lahan kontrol (tanpa LCPKS).

\section{DAFTAR PUSTAKA}

Budianta, D. (2005). Potensi Limbah Cair Pabrik Kelapa Sawit sebagai Sumber Hara Tanaman Perkebunan. Jurnal Dinamika Pertanian , 20(3):273-282.

Dinas Perkebunan Indonesia. (2007). Tingkat Permintaaan Minyak Nabati. Jakarta.

Direktorat Jenderal Perkebunan. (2019). Luas areal perkebunan kelapa sawit. Jakarta.

Hanafiah, K. A. (2005). Dasar-Dasar Ilmu Tanah. Jakarta: PT. Raja Grafindo Persada.

Hardjowigeno, S. (2003). Ilmu Tanah. Jakarta: PT. Mediyatama Sarana Perkasa.

Hardjowigeno, S. (2007). Ilmu Tanah. Jakarta: Akademi Pressindo.

Loekito, H. (2002). Teknologi Pengelolaan Limbah Industri Kelapa Sawit. Jurnal Teknologi Lingkungan , 242-250.

Orji, M. U., Nwokolo, S. O., \& Okoli, I. (2006). Effect of palm oil mill effluent on soil microflora. Nigerian Journal of Biology , 20(2) : 1026-1031.
Perkebunan, D. J. (2019). Luas Perkebunan Kelapa Sawit.

Rahayu, A. S., Karsiwulan, D., Yuwono, H., Trisnawati, I., Mulyasari, S., Rahardjo, S., et al. (2014). Konversi POME menjadi Biogas. Winrock International, $1-96$.

Saputra, F. (2017). Pengaruh Aplikasi Limbah Cair Pabrik Kelapa Sawit terhadap Serapan Hara N, P, dan K pada Tanaman Kelapa Swit.

Silalahi, B. M., \& Supijatno. (2017). Pengolahan Limbah Kelapa Sawit (Elais guinnensis Jacq.) di Angkasa Estate, Kalimantan Selatan. Bul. Agrohorti, 5(3) : 373-383.

SNI 06-6989.10.2004.Air dan air limbahBagian 11: Cara uji derajat keasaman $(\mathrm{pH})$ dengan menggunakan alat $\mathrm{pH}$ meter. Hal. 2-4

SNI 06-6989.15-2004. Cara Uji Kebutuhan COD dengan refluks terbuka secara titimetri. Hal 1-4

SNI 6989.59:2008. Metoda Pengambilan

Contoh Air Limbah. Hal.5-13

SNI 6989-72-2009. Cara Uji Kebutuhan BOD. Hal 2-5

SNI 6989.10.2011. Air dan air limbah-Bagian 10: Cara uji minyak dan lemak secara gravimetri. Hal. 1-4

Susilawati, \& Supijatno. (2015). Pengolahan Limbah Kelapa Sawit (Elaeis guineensis Jacq.) di Perkebunan Kelapa Sawit, Riau. Bul. Agrohorti, 3 (2) : 203-212. 